\title{
SF 268
}

.B82

Copy 1

A TREATISE

ON

\section{BUTTERINE,}

AND 0.1

BuTTER AND ITS DISEASES.

\author{
BI \\ BRAUN \& FITTS, \\ Manufacturers of \\ FINE BUTTERINE, \\ No. 229 S. Water Street, \\ CHICAGO, ILLS.
}

I SS6. 



\title{
A TREATISE
}

\author{
๙ \\ BUTTERINE,
}

axp ox

\section{BUTTER AND ITS DISEASES.}

BY

BRAUN \& FITTS,

Manufacturers of

\section{FINE BUTTERINE, No. 229 S. Water Street,}

CHICAGO, ILLS,

I 886. 
Entered according to Act of Congress, in the year eighteen hundred and eighty-six, Bi BIRAUN \& FITTS,

In the office of the Librarian of Congress, at Washington, D. C. 


\section{PREFACE.}

The object in publishing this pamphlet is to place before the public, Butterine in its true light, and to remove the many prejudices existing against it growing out of the erroneous statements and outrageous falsehoods published by interested parties. Convincing proof will be found in the few lines contained in this pamphlet that Butterine is a pure and healthy food, being, as it is, indorsed by the most prominent Professors and Chemists in this country and in Europe, and also by the United States government.

We also wish to call the attention of consumers to the many impurities liable to exist in Butter and the unsound, unhealthy and diseased condition of a large per centage of the Butter made. Read carefully the analysis of Prof. M. Delafontaine and be convinced. 



\section{INDEX.}

PAR'T I.

Butterine................................... 7 to 12 .

PART II.

Butter and Its Diseases............................ 13 to 16 .

"Prejndice is a thief and robs you of many good things" - and dollars. 



\section{PART I.

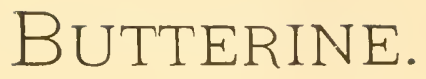

Oleomargarine or Butterine was first discovered by the celebrated Prof. Mege, of Paris, as a fit substitute for Butter. The French Government had for some time been at a loss to know how to obtain sufficient good Butter to supply their armies, and when they could obtain an ample supply it would become strong and rancid before it could be consumed. These facts induced the Government to offer a large reward for a Butter substitute. This led to the discovery made by Prof. Mege, and so well satisfied was the Government with the substitute that it was immediately adopted as food for its armies. Butterine is made from the following substances: Beef Suet, Leaf Lard, finest Creamery Butter, Cream and Salt, and we herewith present an extract from the statement made by Prof. Henry Morton, of the Stevens In stitute of Technology, Hoboken, New Jersey, before the Senate Committee of Agriculture, which committee was appointed by Congress to investigate the merits of the Butterine question:

STATEMENT OF PROF. IIENRY MORTON.

Professor Morton: The subject is one which has been of great interest to all scientific men from the time of the original discovery by Mege. Many persons have been interested in it, and have followed it up. I have been frequently called upon to examine processes and superintend operations where modifications in the manufacture have been suggested, and so on, and specimens have been bronght to me as a chemist to examine from time to time microscopically and chemically. When the substance was first introduced the question was raised as to whether it could be distinguished from Butter by any test, and I was led in that way to investigate the subject, and to examine as to all the properties which it exhibited, as well as to compare different samples of it, and I have in my experiments in this line examined great numbers of specimens of Oleomargarine prepared as Butter, and of Oleomargarine Oil for the 
preparation of Butter, from all parts of the country, and also have visited factories very frequently, and spent long periods there. I have remained as long as a week in one of these factories continuonsly, sometimes spending the night as well as the day there in order to watch the process completely, and see the operation from begining to end - to see what was put in and what was not, and to observe what was done and what was not done.

In the course of these examinations I liave reached the conclusion, fomded on these observations, that the material is of necessity a pure one, and camnot possibly be unwholesome, and is, in fact, in. that sense, thoroughly desirable and safe article of fool. I will express as briefly as I can my reasons for this opinion, and state the facts on which they are founded.

In the first vlace, I have found, as a matter of observation, that fat which is to be used in the manufacture of Oleomargaxine, if it is in the slightest degree tainted before the manufacture begins, if it is not strictly fresh, if it is not taken almost directly from the slaughtered animal, if is allowed to stand in a barrel for a few homrs in ordinary weather or in cold weather, if put in a barrel with any animal heat in it for a few hours, then an incipient change begins which, in the succeeding process, is exaggerated so that an utterly offensive material is produced which conld not be used for any such purpose.

Senator George: Offensive to the smell and taste?

Professor Morton: Offensive both to the smell and taste, so much so that no one could eat it or endure it ; it is very disagreeable. The only way to avoid that is to use extreme care in the collection and preparation of the material, and in the subsequent processes, after it has been cleaned and washed, by melting it carefully and then allowing it to settle, and straining it so that all the animal fiber of eyery sort is removed. It is next submitted to a treatment by which the stearine is removed, and what is left is almost identically the same in composition as butter made from milk and cream. Now, if in that process, after the melting has been gone through with, the slightest portion, even a microscopic portion, of the animal tissue, of the fibrous tissue, or anything else but the pure fat is left in the material in the oil, then in this process of crystalizing by which the stearine is removed (which has to be done at a temperature of abont $S 0$ (legrees), the result will be that the material will become putrid and utterly offensive. I liave seen that done over and over again where there has been a little carelessness in the filtering or cleaning, or want of proper treatment where the fat has not been heated liot enough during the rendering, so that there be a little fiber left in. Under these circumstances, during this process of crystalizing, a fermentation takes place wich is very offensive, almost unendurable, and they have to throw the eutire mass into the tanks used for the refuse to make tallow of, as it would not be food fit for use at all.

Senator George: Is there no way of counteracting this offensive condition?

Professor Morton: No way whatever.

The Chairman: Have you never found any of these tissues in Oleomargarine after it was manufactured, under the microscope? 
Professor Morton: Never. This statment I make is important as to the effect of the process; that is, the putrefying effect which would result from a neglect to thoroughly separate the fatty matter from the fiber. This is important because it bears upon the question which has been raised as to whether the germs of disease could in any way be carried from the animal into the product. These germs, in the first place, have never been found. There is no scientific testimony anywhere that they have ever been found in the fat of animals. They are always found in the muscles and tissues, but never in the fat.

Senator George: Then the germs of disease from diseased cattle are never found in fatty substances?

Professor Morton: No, sir.

The following is an extract from the testimony of Prof. C. F. Chandler, President of the Board of Health of New York, taken before a committee of the United States Senate at Washington:

"I would simply like to say further that I have carefully studied this subject, and I have not found, either in this country or abroad, any chemist or physiologist, who has any standing in the profession, who has ever uttered an opinion adverse to artificial Butter. Certain persons who have no standing whatever, in the employ of these parties who are paid to hound this article of food, have put forth statements, and one of them has published pictures attemping to disgust people by illustrating what he alleged he saw in these compounds under the microscope. His statements are entirely without foundation. He made similar ones against the Croton water in New York when

Senator Gibson: Is dairy Butter colored?"

Prof. Chandler: "Yes, sir; more than half the time."

Senator Gibson: "Is it a product or a manufactured article?"

Prof. Chandler: "Butter is a manufactured article just as Butterine is a manufactured article."

Senator Gibson: "As a practical chemist, will you tell us some of the differences in the manufactured product?"

Prof. Chandler : "The finished dairy Butter and the finished artificial Butter are the same. There is nothing in one not found in the other. All the percentages of stearine, palmatine and olein, and the percentages of water and salt, are practically the same in the two kinds of butter. I am speaking of the finished article when it is put on the table, and I say they are essentially the same thing."

The testimony in favor of Butterine before the Senate Committee covered 264 pages of closely printed matter.

Oleomargarine, or Butterine, is indorsed by the following well known authorities:

C. F. CHIANDLER,

President Nero York Health Department.

PROF. GEORGE F. BARKER,

University of Pennsylorania. 
DR. HENIRY A. MOTT, JR., New York.

FROF. S. C. CALDWELL, Cornell University.

PROF. S. W. JOHNSON, Yale College.

PROF. C. A. GOESSM IN, Massachusetts Agricultural College.

PIROF. HENRY MORTON. Stevens Institute of Technology, IIoboken, N.J.

PROP. CHAS. P. WILLIAMS, Plitcodelphia.

PROF. W. O. ATWATER, Wesleyan University, Middletozon, Conn.

PROF. J. W. S. ARNOLD,

University of Neno Fork.

Also, by the greatest chemist and sanitary authority of England, Ur. Lyon Playfair, who stated in his remarks before Parliament-

"Bad Butter is a fraud upon the poor, and Oleomargarine would sooner or later drive it out of the market; also, that Oleomargarine did not become rancid so readily as Butter."

John H. Rauch, M. D., Secretary of the Illinois State Board of Health, in giving testimony regarding Butterine, says:

"Nothing in the manufacture or the material used is detrimental to health, and the products are wholesome."

In addition to the prominent names given we can also add that of Dr. Oscar C. De Wolf, of the Health Department of Chicago, who has time and time again indorsed Butterine as a wholesome food product, and stated that it was far superior to the bulk of Butter on the market.

Other scientitic men of the East say:

"Nothing objectionable exists in the original material, nor is anything objectionable added during the process, and the operations are conducted with the utmost cleanliness. Il conlains the same constituents as drainy Buller. It is palatable and wholesome, and can be made of uniform quality the year romd. Il is in crery respect superior as an articte of food to a large moportion of daring Butter, and entively unerceplionable in erevy respect."

As regards the wholesomeness of the Butterine made by us. we take great pleasure in publishing the following letter received 
from Prof. J. H. Long, of the Chicago Medical College, and also the Chemist of the Health Department of Chicago:

JOHN H. LONG,

ANALYTiCal Chenist.

LABORATORY :

Chicago Medical College,

Cor. Prairie Ave. and Twenty-sixth St.

Chicago, Sept. 1, 1886.

Messis. Braun \& Fitrs-Gentlemen: Having examined carefully your process of Butterine manufacture, and after making full microscopical and chemical analysis of the products, I am able to say that I consider the same perfectly clean and wholesome and free from any injurious substance whatever.

\section{Yours respectfully, $\quad$ J. H. LONG.}

Scandalous reports liave been lieard and ontrageously false remarks have been made about Butterine, mostly inspired by a "clique" of Butter speculators, who now fear their occupation is gone. Their mode of money making is to buy Butter at a very low price when it is very plenty, and in the winter when the supply is lighter, after holding it three to six months, foist it upon tlıe public at fabulous prices; also, by a lot of Dairymen, or Cow Barons, who are situated in such sections of the country where it is impossible to produce good Butter, and who have been unable to find a market for their class of goods.

Although Butterine manufacturers liave been persecnted and their product maligned, like Banquo's ghost, it would not down, and this brancl of industry has, in spite of all, kept pace with the age of progression, and the consumption of Butterine has constantly increased. Our firm alone produced nearly nine million $(9,000,000)$ pounds the past year, which proves conclusively that the goods must possess great MERIT. Had the Butter "clique" been able to prove Butterine unwholesome, or that it contained any injurious substances, they would have done so before Congress, and that body would have prohibited the manufacture of it. But they could only prove that it was a great competitor of Butter, and if let alone wonld crush out of the market the sale of all of the poorer grades of Butter, leaving tons of it to go to the soap factories. To make a market for this unwholesome product of the cow was their aim and Congress was implored to impose a tax in their interest.

Good Butterine can only be made by using fine, fresl, healthy Creamery Butter and pure Cream. When poor Butter is used 
the result is poor Butterine, but the consumer cannot be deceived if he uses his faculties of taste and smell.

If Butterine is placed before you and it tastes good, and smells sweet and rosy, accept it, for it is good; if it lacks these qualities, reject it. The same test is applicable to Butter. We would also incidentally mention that the members of our firm use Butterine on their table.

In conclusion, we would say that our product is a wholesome article of food, and equal in quality to the finest Butter made. 'To those who have already used it it is needless to further recommend it, and to those who bave not, we ask them to give it a trial, confident that it will be preferred to the bulk of the socalled Creamery Butter.

\section{OUR GOODS CAN BE OBTAINED FROM YOUR} DEALER. 


\section{PART II. \\ BUtTER AND ITS DISEASES.}

Pure Butter is the fatty substance properly extracted from pure milk, taken from a healthy cow, fed on clean, healthy food, and watered with clear, pure water. This grade of Butter is perfect in every respect, showing in a high degree a pleasant aroma, very easily detected by that infallable test, the sense of smell, and that of taste. Such Butter is a Luxury, and owing to the limited supply and consequently high price, only within the reach of the few with long purses.

Impure Butter and diseased Butter comprises all other grades, and the bulk of the Butter offered for sale on the markets. The causes of this impurity are many. Amongst the most common are the following: Want of cleanliness, and system in the Dairies and Creameries; neglect in gathering and churning the cream before the germs of decomposition have been developed; cows feeding upon obnoxious weeds, and drinking stagnant and slimy water, or housed in dirty, filthy barns; also, the placing of milk and cream in untidy kitchens, visited at will by pigs, chickens, dogs, cats, etc. Cream and milk set in such places is also liable to be contaminated with diseases with which the houselıold becomes affected. For illustration the following colloquy occurred during the Senate investigation:

Senator George: What are the comparative risks of the introduction of disease germs into Oleomargarine and pure Butter?

Professor Morton : They are cousiderably greater in pure Butter. It is easier te get germs into milk, and milk is never heated in the making of Butter, so that nothing is done to protect it. The risk of introducing the germs of consumption from cows suffering with that clisease would be far greater in the manufacture of Butter than in the manufacture of Oleomargarine.

Senator Gibson: What is the point of temperature to which Oleomargarine is raised in the process of manufacture?

Professor Morton: The individual particles of it come very nearly to the boiling point of water; just to a good cooking temperature. 
Senator Gibson: Would that destroy the germs necessarily?

Professor Morton: It would destroy them under all circumstances.

Last, but not least to the greed of a merciless ring of speculators, who put away the fresh Butter during the snmmer months and every fall and winter manipulate prices, outrageously high, for the purpose of securing large protits, by foisting their old, lancid stuff on the market.

In their report the Dairy and Food Commission of Ohio tell of the "adroit but grossly unlawful manner in which the country dealer works over for the city market Butter of divers colors and qualities, and divers degrees of composition." As indicated in various ways, the incoming of a healthful Butter substitute was a movement toward pure Butter in fact. The promise now is for full publicity as regards the making of both Butter and Oleomargarine.

Every buyer cannot be a chemist; nor is it necessary. Bring your nose with you, and apply the same test in buying Butter that you would in choosing between a rabbit and a skunk. This rule will apply to all descriptions of food. That which has any foreign flavor, or through age shows signs of decay, cannot be pure or wholesome. Some future congress may protect the bnyer, by compelling the virtuous Dairymen and highly moral and honest Butter dealer and speculator to brand Butter under its proper and honest grade. Then a provision store will be like a large scrap-book, with its numberless mottoes; namely,

\section{"Gilt Edge Butter, Three Montus Old.,"}

"Choice Butter, Made From Mulk TAKen From a Sick Cow.'

"Gint Enge Butter, Six Montis OLD ND

VERY RANCID." 
"Gilt Edge Butter,

Well Filled With Disease Germs."

\section{"Choice Buttei:}

IN ITS

Second Stage

OF

DeCOMPOATton."

\section{"Ladle Packed Creanery}

Made From

Alu Kinds of Diseased But'er,

WELL HASHED

A ND

HALF IVASIIED."

"Fancy Butter, Made From

Milk Taken From Cows Who IVere

Compelled to Quencin Tineir

Thirst in Stagnant Pools of

SimuY Water."

These will be a few of the most conspicnous finger boards that will guide the future bnyer.

It is a notorious and undisputed fact that eighty $(80)$ per cent of all the Butter received is unfit for food, and, instead of being corsigned to the human stomach, should be sent to the soap factory.

Numerous establishments in the country and city buy up the odds and ends of Bntter, called "packing stock," which comprises a conglomerated mess of rejections of Butter for repacking purposes, and bring it out under varions high flown names and sold to consumers as fresh country Butter. 
We submit the following analysis of Butter by one of the most eminent chemists of Chicago :

M. Defafontaine,

Aramitical and Consultixa Chemist,

81 South Clark Str., Room 23.

Cincago, Sept. 15, 1886.

Butter made with care so as to insure its sweetness and preserve its flavor' is rightfully a most popular article of food. 'The ready sale of that staple seems to have the effect of stimulating carelessness on the part of many of the producers, or what is worse, to have induced them to seek the means of putting as little real Butter as possible in their ontput. At least, such is the conclusion which the writer has come to from his numerons examinations of Butter in Chicago during the last fifteen years.

Gemuine Butter, witl keeping qualities, contains at least 80 per cent. real Butter, at most 10 per cent. water, 7 per cent. salt and 3 per cent. casein.

Here in Chicago the writer has almost invariably found less Butter and more water, salt and casein. Not infrequently have the proportirns been nearer Butter 65, water 15 to 20, salt 8 and casein 7 to 9 . The rancidity of Butter is chiefly owing to changes in the Butter fat produced by the putrifaction of the casein, and, therefore, the greater the amount of casein and the more the chance of rancidity. The alterations in the casein are also attended by the formation of injurious products. some of which rank among the most deadly poisous, as shown by cases of poisoning from ice cream and cheese.

"Butter is easily digested by most persons except when it becomes rancid. It then causes dyspepsia and diarrhea," says an eminent hygienist, and his judgment is confirmed by the experience of many.

Rancid Butter is nothing less than decaying food, and as such it contains poisonous substance, the presence of which is readily demonstrated by chemical analysis. One of thern is butyric acid - a very irritating acid-a very small quantity of which often suspends gastric digestion for hours. What effect small doses of this and other similar poisons frequently ingested have on the digestive powers of people, especially of children or women, is for the reader to imagine.

Whilst the writer heartily indorses all the good that is said of pure, genuine, well made Butter, he feels constrained to say, from his own personal observations, a very large proportion of the article sold as such on our market is more of a danger to public health than a thing of joy for the consnmer.

M. Delafontaine. 

LIBRARY OF CONGRESS

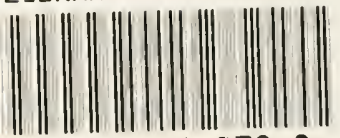
0000891378 A 